\title{
A STUDY ON LIPASE:REVIEW
}

\section{PATEL $S^{1}$, ANDHARE $P^{2}$, MARCHAWALA $F^{2}$, BHATTACHARYA $I^{2}$ AND UPADHYAY $D^{2 *}$}

1: Student, M. Sc. Microbiology, Parul Institute of Applied Sciences, Parul University, Post Limda, Waghodia, Gujarat, 391760

2: Assistant Professor, Parul Institute of Applied Sciences, Parul University, Post Limda, Waghodia, Gujarat, 391760

*Corresponding Author: Dr. Dhwani Upadhyay; E Mail:dhwani.updhyay82123@paruluniversity.ac.in; Tel: +919558021474

Received 22 ${ }^{\text {nd }}$ Jan. 2021; Revised 24 ${ }^{\text {th }}$ Feb. 2021; Accepted 25 ${ }^{\text {th }}$ March 2021; Available online $1^{\text {st }}$ April 2021 https://doi.org/10.31032/IJBPAS/2021/10.4.1040

\section{ABSTRACT}

Lipase are a class of enzymes which catalyse the hydrolysis of long-chain triacylglycerol's and fatty acids. Lipases are produced by plants, animals and microorganism including bacteria and fungi. Biological Processes are very important stage of optimization the to increase and improve the efficiency of cost.The aim to use of lipases in effluents with high lipid content and hydrolyzetriacylglycerided, reducing of suspended lipids and solids. The catalysing reactions of lipases are highly effficient in both aqueous and non-aqueous media because the high stability in extremes of $\mathrm{pH}$, temperature and organic solvents.Lipases enzymes observation to bulk enzymes and high-value of production. Lipases are an important group of enzymes with various applications in the chemical detergent biocatalytic of pharmaceutical, food industry, making the fine chemical, esters, agrochemicals, leather industry, paper industry use to biosensor,cosmetics and bioremediation.

Keywords: Enzymes, Lipases, history of lipases, Characteristics of lipase \section{INTRODUCTION}

Lipases are serine hydrolyses that the catalyze both synthesis and hyrolysis of long- chain triacylglyceroles. Lipases are the most versatile enzyme widely used in biotechnological applications due to the lipases are carboxylic ester hydrolyses attracting an enormous attention [1]. Lipases ubiquitous enzymes which are 
found in bacteria, fungi, plants and animals.

The microorganisms are usually grown in nutrient medium supplemented with nitrogen source, carbon source and phosphorous [2]. Triglycerides, glycerol and bile salts are usaully inducer for the production of lipases [3]. The lipases are used as biocatalysts with modification of their physiochemical factors such as stability, specificity, $\mathrm{pH}$ and temperature [4]. Lipases are used in biotechnological applications such that textile and dairy industries, detergent industry, biodiesel and oil processing and production of surfactants they have been obtained from microorganisms [5]. The lipases are an important role in processing of polyunsaturated fatty acids, a food colorant, g-linolenic acid, methyl ketones of flavour molecules characteristic of blue cheese [6]. In $19^{\text {th }}$ century of the industrial revolution activities that greatly contributed to environmental depletion. Lipases enzyme that hydrolyzed insoluble oil droplete and converts to the soluble was determine by clade Bernad, 1856 in pancreatic juice [7]. Only a few lipase-producing bacteria were characterized, but research was intensified, became enzymatically active in organic solvents [8]. The long chain triacylglycerol are the normal substrate for lipases [9]. Lipases and esterase are very useful for biocatalyst. They are hydrolyses on carboxyl ester bonds. 3-D structure of lipases show a hydrolyse's where the catalytic action of serine [10]. Lipases are useful for all commercial extracellular isolated from different bacterial species including pseudomonas and Bacillus. Among the pseudomonas species, pseudomonas aeruginosa, pseudomonas fluorescence and pseudomonas cepacia are the lipases of major producer [9]. The important of lipases enzymes, the study was aimed to the bacterial lipases isolates to the higher activites such as natural and alkaline $\mathrm{pH}$. The microbial lipases are detergent industry growth of industry to innovative key factors of lipases with chlorine bleach [11]. Bacterial lipases are lipoprotein however few extracellular bacterial lipases are glycoprotein [12].

\section{HISTORY OF LIPASE}

Lipases enzyme that hydrolyzed insoluble oil droplets and converts to the soluble was determine by clade Bernad, 1856 in pancreatic juice.Lipases wasindustrialized from the fungus thermomycesl anugiwnosos and in aspergillus oryza in 1994 was first commercial recombinant lipase [11]. The Bacillus pyocyaneus, Bacillus prodigiosus and Bacillus flurorescens have been noticed lipase enzyme as early as in 1901. The lipases producing bacteria like pseudomonas aeruginosa and pseudomonas flurorescens [13]. Lipases have been degestive for human consumption either in the crude 
mixture with other hydrolases obtained for the animal pancreas. They are various types of substrate and environmental factors such as temperature, pressure, $\mathrm{pH}$ and high conversion rates and highly natural catalysts [14].

GENERAL CHARACTERISTICS OF LIPASE

The $1^{\text {st }}$ lipolytic enzyme was discovered by clude Bernard in 1856, and after that it recognized from microorganism, plants and animals(fungi, bacteria and yeast). Lipases arehydrolyze insoluble substrates and dissolved in water to more lipolytic products. General characteristics of lipase is a pervasive enzyme which is essential for physiological importance and industrial uses. Lipases are glycerol and free fatty acids to breakdown of triglycerides. [15]. Lipases are catalytic part of the partical, they are serine hydrolases containing. where $\mathrm{G}=$ glycine, $\mathrm{S}=$ serine, $\mathrm{X} 1=$ histidine, $\mathrm{X} 2=$ glutamine or aspartic acid. The serine proteases also for characteristic of structure. A significant role in designing and structuring lipases for specified play role of 3-dimensional structure[15].

Lipases are catalysing unique in fat hydrolysis to glycerols and fatty acids, which can been water-lipid border take place, and in terms of non-water environment of a reverse reaction after than contact with and insoluble substrate in water, a change in the enzyme's conformation occurs. The interfacial activity of phenomenon is an area of intensive studies performed by biochemists, crystallographers, chemists, biochemical engineers and molecular biologists [16].

\section{VARIOUS CATEGORIES OF LIPASE}

Categories of lipases are in two different based on the specificity and sources. The all enzymes which need to be compared have been the same or at least related substrates [17]. The lipase enzyme have been found for different species such as plant, animal, insects and microorganism [18]. Microbial lipases have expanded a lot of consideration due to the higher functional ability, sustainability at extreme condition, stability in natural dissolvable, chemo-selectivity, enantio-selectivity. Lipases are widely used in oil processing detergent formulation [19].

Lipases based on which can be grouped into three major categories:

1)Substrate-specific

2) Regioselective

3) Enantioselective

1) Substrate-Specific Lipase: lipases have been used in substrate-specific reaction, They selectivity act on a mixture of crude raw materials in a specific substrate, a synthesis of demonstrated by lipase use in biodiesel production. Generally, substrates that can be act by substrate-specific lipase include fatty acids and alcohol [20]. 
2) Regioselective Lipase: The regioselective lipases are importance to pharmaceutical industries and chemical especially in the production of isomeric compounds that exhibit optimal function. The region selective lipases was finding of include acylation of ferulic acid with Quercetin using Rhizopus [21].

\section{DIFFERENT BIOREACTORS USED} IN LIPASE PRODUCTION

\section{Tray bioreactors (TB)}

The made of a chamber up to tray bioreactors Where controlled air (Cabin temperature, cabin air and cabin humidity) was distributed in different trays. The solid substrate layer, usually between 5 and 15 $\mathrm{cm}$ deep every trays. This trays are generally open from the top and have holes in the bottom which can be support to exchange of gases. The solid substrate can be carried out with the help of hand mixing of the solid substrate, but it can been only performin a day [22].

\section{Packed-bed bioreactors (PBB)}

Packed-bed bioreactor was frequently a static bed on top holed plate from which air is blasted. In other packed-bed bioreactor design, air was blow through a hole between of the bed. In last 25 years, PBB have get more modelling and experimental consideration. The most unique characteristic of PBB is that it have been no moving parts (Mechanical) hence it reduces the cost of maintenance, operation and construction. Axial dynamic temperature is observed in PBB processes [23]. The water and temperature are increases of the air will carrying quantity. Although, $65 \%$ of the cellular metabolism in heat produced is remove by phenomenon evaporation, it can be decreases the moisture content of solid substrate as a result of limited to cellular growth [24]. In PBB bed was not mixed dueto moisture regulation improper. The most advantageous of water to enhance heat removal. The lipase production of low at small scale and in various bioreactors designs is noteworthy [15].

\section{IMPACTS OF PHYSICAL ELEMENTS}

Physical elements such as $\mathrm{pH}$, Temperature, agitation and inoculum have extraordinary impact on the lipase creation.

Effect of temperature on lipase production: The Temperature is most important role in the production of microbial lipases. They play vital role in the lipase production. The higher biomass concentration of lipase is mostly observed at $37 \mathrm{C}$ [25]. Microorganism such as Bacillus cereus, Enterobacter agglomerans and Pseudomonas $s p$. showed $30^{\circ} \mathrm{C}$ as the optimum temperature for growth and lipase production [18].

Effect of pH on lipase production: The bacterial lipases in Generally, have been alkaline $\mathrm{pH}$ optimal or neutral $\mathrm{pH}$. The neutral $\mathrm{pH}$ and alkaline conditions the lipase production in yeast cells and 
bacterial [25]. Alipase was good production observed by the Rhodotorul aglutinis HL25 when the production medium $\mathrm{pH}$ was maintained at nearly neutral $\mathrm{pH}$. The enzyme was normally used in stored at $4^{\circ} \mathrm{C}$. Determined the optimal $\mathrm{pH}$ wasat $30^{\circ} \mathrm{C}$ in buffer solution and ranging from $\mathrm{pH}$ values to $11[26]$.

\section{APPLICATION OF LIPASE}

Lipases are commonlyused in the processing of fats and oil production, food processing, detergents and degreasing formulations, the synthesis of fine chemicals and pharmaceuticals [11]. Recombinant DNA technology will increase the production of lipase and cellulose, such as most specific and industrial enzymes. The use of Lipases as biological catalysts in the production of other products (such as ingredients) and their application (in making fine chemical) [13].

Table 1: Showing the various industrial applications of microbial lipases

\begin{tabular}{|c|c|c|c|}
\hline Industry & Action & Application & Reference \\
\hline Detergents & Hydrolysis of fats & Removal of oil stains from fabrics & {$[8]$} \\
\hline Bakery foods & Flavor improvement & Shelf-life prolongation & {$[11]$} \\
\hline Beverages & Improved aroma & Beverages & {$[11]$} \\
\hline Fats and oils & Transesterification, Hydrolysis & Cocoa butter, fatty acids, Glycerol & {$[15]$} \\
\hline Dairy foods & $\begin{array}{c}\text { Hydrolysis of milk fat, cheese } \\
\text { Ripening }\end{array}$ & $\begin{array}{c}\text { Development of flavoring agents in } \\
\text { milk, cheese, butter }\end{array}$ & {$[15]$} \\
\hline Leather & Hydrolysis & Leather products & {$[27]$} \\
\hline pharmaceuticals & Transesterification, hydrolysis & Speciality lipids, digestive aids & {$[27]$} \\
\hline
\end{tabular}

\section{CONCLUSION}

Lipases are serine hydrolyses that catalyze the synthesis as well as the hydrolysis of long- chain triacylglycerol's. Lipases are enzymes that have the capacity to hydrolyze of fats into fatty acids and glycerols. Lipases are enzymes that aid in the digestion, transport and processing of dietary lipid (fats and oils). The long chain triacylglycerol are the normal substrate for lipases. Bacterial lipases are glycoproteins in general, but certain extracellular bacterial lipases are lipoprotein. The lipases are used as biocatalysts with modification of their physiochemical factors such as stability, specificity, $\mathrm{pH}$ and temperature.
Lipases are used in variety of industries, including food, pharmaceutical fine chemical, oil chemical, biodiesel and industrial detergent. Tray Bioreactors are made up of a chamber and a tray. In this case, the controller air (Cabin air, cabin temperature and cabin humidity) is distributed in various trays. They have a wide range of applications in the industries of fat and oil processing, food industry, detergents, pulp and paper industry, tea processing, cosmetics and biosensors.

\section{ACKNOWLEDGEMENT}

It's our privilege and honour to express our sincerest gratitude to the Parul University, Vadodara, Gujarat for providing me all the 
necessary support and facilities including state of the art infrastructural facilities with advanced technological scientific laboratories and everything else that was required to carry out this work.

\section{REFERENCES}

[1] Alhamdani, M., and Hanaa Jaffer Jabbar Alkabbi. "Isolation and identification of lipase producing bacteria from oil-contaminant soil." J Bio Agri Health Dec2016; (6): 1-7.

[2] Rajeshkumar, V. S. Mahendran et $a l$; "Isolation and identification of lipase producing organisms from diverse soil samples of Kolli hills." International Journal of Current Microbiology and Applied Sciences. 2013; 2(5): 205-210.

[3] Kishore, J. P., Z. Chopdia Manojkumar, and T. M. Raghunath. "Lipase biodiversity." Indian J Sci Technol. 2011; (4): 971-82.

[4] Bornscheuer, Uwe T. "Microbial carboxyl esterases: classification, properties and application in biocatalysis." FEMS microbiology reviews. March 2002; (26)1: 73-81.

[5] Ali, Chaudhry Haider, et al; "Significant enhancement of Pseudomonas aeruginosa FW_SH1 lipase production using response surface methodology and analysis of its hydrolysis capability." Journal of the Taiwan Institute of Chemical Engineers. July 2015; (52): 7-13.

[6] Verma, S. H. U. B. H. A. M., and KANTI PRAKASH Sharma. "Isolation, identification and characterization of lipase producing microorganisms from environment." Asian J Pharm Clin Res. 2014; 7(4): 219-222.

[7] Ilesanmi, Oluwaseye I et al; "Isolation, optimization and molecular characterization of lipase producing bacteria from contaminated soil." Scientific African. 2020; (8): e00279.

[8] Jaeger, K. E., B. W. Dijkstra, and M. T. Reetz. "Bacterial biocatalysts: molecular biology, threedimensional structures, and biotechnological applications of lipases." Annual Reviews in Microbiology. 1999; 53(1): 315351.

[9] Saadatullah, Malook I et al; "Isolation, identification and characterization of a lipase producing Pseudomonas." J. Biomat December 2018; (2): 51-57.

[10] Mohan, T. S., Palavesam, A., et al; Isolation and characterization of lipase-producing Bacillus strains from oil mill waste. African journal of 
Biotechnology. 2008;7(15):16845315.

[11] Chandra, Ranjan Singh et al; "Microbial lipases and their industrial applications: a comprehensive review." Microbial Cell Factories. August2020; 19(1): $1-42$.

[12] Alhamdani, M., and Hanaa Jaffer Jabbar Alkabbi. "Isolation and identification of lipase producing bacteria from oil-contaminant soil." J Bio Agri Health. November2016; 6(19): 1-7.

[13] Fariha Hasan, Aamerali shah et al; "Methods for detection and characterization of lipases: a comprehensive review. " Biotechnology advances. June, 2009; 27(6): 782-798.

[14] Yanyan Huang, Jinsong Ren, et al; "Nanozymes: classification, catalytic mechanisms, activity regulation, and applications." Chemical reviews. February 2019; 119(6): 43574412.

[15] Ritika Joshi and Arindam Kuila. "Lipase and their different industrial applications: a review." Brazilian Journal of Biological Sciences. Aug. 2018; 5(10): 237-247.
[16] Lason Elwira and Jan Ogonowski. "Lipase-characterization, applications and methods of immobilization." 2010: 100-102.

[17] Leo Brady, Andrzej M et al; "A serine protease triad forms the catalytic centre of a triacylglycerol lipase." Nature $343 . \quad$ February 1990; 343(6260): 767-770.

[18] Yongsheng Chen, Jiangwei Liu et al; "Lipase-catalyzed synthesis mechanism of tri-acetylated phloridzin and its antiproliferative activity against HepG2 cancer cells." Food chemistry. March 2019; (277): 186-194.

[19] Jaeger, Karl-Erich et al; "Microbial lipases form versatile tools for biotechnology." Trends in biotechnology. 9 September1998; 16(9): 396-403.

[20] Nipon Sarmah, D. Revathi et al; "Recent advances on sources and industrial applications of lipases." Biotechnology progress. Jan 2018; 34(1): 5-28.

[21] Mayordomo I, Randez-Gil F et al; Isolation, purification, and characterization of a cold-active lipase from Aspergillus nidulans. J Agric Food Chem. Jan 2000; 48(1): 105-9.

[22] Ritika Joshi and Arindam Kuila. "Lipase and their different 
industrial applications: a

review." Brazilian Journal of

Biological Sciences. August 2018;

5(10): 237-247.

[23] Aruna Khan and Karim Khan.

"Optimization studies on

production and activity of lipase

obtained from Staphylococcus

pasteuri SNA59 isolated from

spoilt skin lotion." Int J

CurrMicrobiolAppl Sci. 2014;

3(5): 326-347.

[24] Melissa LE Guttra Mateus G.

Godoy et al; "Production of an acidic and thermostable lipase of the mesophilic fungus Penicillium simplicissimum by solid-state fermentation. "Bioresource technology. November 2009; 100(21): 5249-5254.

[25] Devaraj Bharathi, Rajalakshmi G et al; "Optimization and production of lipase enzyme from bacterial strains isolated from petrol spilled soil. "Journal of King Saud University-Science.

Octomber, 2019; 31(4): 898-901.

[26] Mobarak-Qamsari, E., R. KasraKermanshahi et al;. "Isolation and identification of a novel, lipaseproducing bacterium, Pseudomnas aeruginosa KM110." Iranian journal of microbiolog. Jun 2011; 3(2): 92.
[27] Vulfson, E. N. "Industrial applications of lipases.

" Lipases. (1994). 